\title{
Лечебная тактика при фибринотораксе
}

Кафедра хирургии им. Н.Д. Монастырского ГОУ ДПо "Санкт-Петербургская медицинская академия последипломного образования Федерального агентства по здравоохранению и социальному развитию": 191015, Санкт-Петербург, ул. Кирочная, 41

\section{V.V.Lishenko, D.A.Zaitsev \\ Therapeutic strategy in loculated pleural exudates}

\begin{abstract}
Summary
Results of treatment of 132 patients with loculated pleural exudates have been analyzed in the paper. Of these, 75 patients were treated with standard methods and 57 patients were treated using a diagnostic and treatment program proposed by the authors. This program included proteolytic enzymes and thoracoscopy under local anesthesia and could be applied in any large hospital in patients admitted with loculated pleural effusion.

Key words: loculated pleural exudate, proteolytic enzymes.
\end{abstract}

\section{Резюме}

В работе анализируется опыт результатов терапии 132 пациентов с плевритами отграниченного характера (фибриноторакс). Из них 75 больных лечились традиционными методами, 57 - с применением предлагаемой лечебно-диагностической программы, в которой использовались протеолитические ферменты и торакоскопия под местным обезболиванием. Применение предложенных лечебнодиагностических мероприятий возможно в любом многопрофильном стационаре, куда поступают пациенты с синдромом плеврального выпота, у которых при обследовании диагностируется фибриноторакс.

Ключевые слова: фибриноторакс, протеолитические ферменты.

На сегодняшний день известно $>80$ легочных и внелегочных заболеваний, сопровождающихся накоплением жидкости в 1 или 2 плевральных полостях [1-3]. При синдроме плеврального выпота значительная доля приходится на плевриты отграниченного характера - т. н. "осумкованные". Основная часть пациентов с плевритами, в т. ч. отграниченными, госпитализируются в пульмонологические и терапевтические отделения, где используются традиционные методы обследования и лечения: общеклиническое обследование, рентгенологическая диагностика, плевральные пункции с последующим исследованием плевральной жидкости [4], а иногда выполняются различные дренирующие манипуляции с участием хирурга. Возникающие трудности в обследовании и лечении таких больных связаны, прежде всего, с невозможностью полноценно санировать плевральную полость и установить этиологию процесса, т. к. пункция плевральной полости при отграниченном плеврите часто бывает неэффективна. Это связано с тем, что выпот имеет желеобразную консистенцию из-за большого количества фибрина или множественных разграничений внутри этой полости, количество которых может варьироваться. Чем больше в выпоте фибрина, тем сложнее санировать плевральную полость. Такой отграниченный плеврит различного объема, с фибринозными включениями, определяют как фибриноторакс. Даже дренирование плевральной полости широкопросветной трубкой в подобных случаях не позволяет полностью санировать плевральную полость из-за описанных характеристик выпота. Без санации плевральной полости исходом такого состояния может стать формирование мощного фиброторакса с развитием дыха- тельной недостаточности или, при присоединении вторичной инфекции, эмпиема плевры [5].

Целью исследования явилось улучшение результатов лечения отграниченного плеврита (фибриноторакса) на основе разработки диагностических и лечебных мероприятий.

\section{Материалы и методы}

Были проанализированы исходы лечения 132 пациентов Александровской больницы (Санкт-Петербург) за период 2005-2009 гг., у которых был выявлен плевральный выпот отграниченного характера (осумкованный плеврит), что составило $48 \%$ от общего числа больных (272 человека) с синдромом плеврального выпота за эти годы. У 75 из них (контрольная группа) обследование и лечение были традиционными. Выполнялись рентгенологическое и общеклиническое обследования, плевральные пункции с последующим исследованием плевральной жидкости, если удавалось ее получить, иногда - дренирование плевральной полости. Возраст пациентов составил 18-80 лет, средний - 49 лет. Среди испытуемых было 57 мужчин и 18 женщин.

При наличии рентгенологической картины, характерной для синдрома плеврального выпота отграниченного характера, выполнялась плевральная пункция широкопросветной иглой. Как правило, удавалось аспирировать жидкость в незначительном количестве (5-10 мл), или пункция была не эффективной, а рентгенологические данные, кроме результатов компьютерной томографии (KT), не позволяли адекватно оценить характер изменений при этом патологическом состоянии. Полноценно сани- 
ровать плевральную полость было невозможно даже посредством дренирования широкопросветной трубкой объемом > 800 мл.

Такая методика диагностики и лечения у 51 пациента оказалась малоэффективной, т. к. добиться полноценной санации плевральной полости не удавалось, при этом этиологию процесса установить также не представлялось возможным. Все пациенты этой группы лечились по описанной программе, принятой для пара- или метапневмонических плевритов, но в связи с неэффективностью терапии в течение 10-14 сут. переводились в специализированные торакальные отделения (плевритные центры) с диагнозом отграниченный плеврит неясного генеза. Из них у 5 пациентов развилась эмпиема плевры (больные были переведены в гнойные торакальные отделения), а у 7 - мощный фиброторакс (через 5-7 мес.) со значительным снижением жизненной емкости легких и проявлениями дыхательной недостаточности.

У 24 пациентов контрольной группы была установлена этиология фибриноторакса, но санировать плевральную полость полностью не удалось. Из них у 3 больных фибриноторакс был следствием плеврита туберкулезной этиологии (переведены в противотуберкулезные диспансеры по месту жительства), у 14 - возник на фоне плеврита неспецифического характера (пара- и метапневмонического плеврита; больные выписаны после лечения с выздоровлением), у 5 пациентов имел место канцероматозный плеврит (выписаны к онкологу по месту жительства), и у 2 пациентов плевральный выпот представлял собой транссудат как следствие сердечной недостаточности различного генеза. При канцероматозном плеврите и накоплении жидкости вследствие сердечной недостаточности после серии пункций произошло частичное отграничение жидкости небольшого объема (100-300 мл), что было выявлено при рентгеноскопическом исследовании плевральной полости после удаления свободной жидкости [6].

Срок лечения пациентов контрольной группы, не переводившихся в другие стационары, составил от 10 до 20 сут., в среднем - 15 сут.

На основе анализа исходов лечения и обследования этой группы пациентов, которые нас не вполне

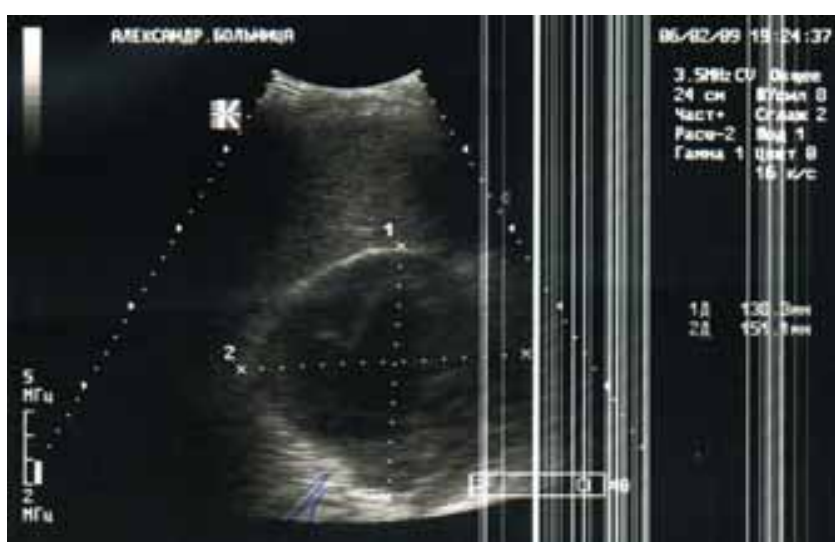

Рис. 1. УЗ-картина отграниченной полости с большим количеством фибрина. Больной Б., 58 лет удовлетворили, в систему лечебно-диагностических мероприятий кроме традиционных методов обследования и лечения были включены обязательное ультразвуковое исследование (УЗИ) плевральных полостей, плеврография, применение протеолитических ферментов (террилитин), микродренирование плевральной полости по Сельдингеру, дренирование плевральной полости 2-просветной трубкой для введения ферментов и антибиотиков. При необходимости выполнялась торакоскопия с биопсией под местным обезболиванием.

Именно с помощью УЗ-сканирования удалось определить точный объем содержимого полости, выдвинуть предположение о его характере, определить наличие внутриплевральных сращений, выбрать оптимальную точку для пункции или микродренирования плевральной полости (рис. 1) в ближайшее время после поступления больного в стационар [3].

Пункция плевральной полости проводилась только после УЗИ. Если не удавалось получить жидкость, то под контролем УЗ-датчика выполнялось микродренирование плевральной полости тонким катетером. Это было целесообразно, когда объем фибриноторакса не превышал 800-1000 мл. При большем объеме плевральную полость дренировали 2-просветной трубкой в нижней точки полости для лучшей эвакуации жидкости после применения протеолитических ферментов. Затем по катетеру или дренажу в плевральную полость вводился раствор, содержащий террилитин, в дозе от 200 до 600 ПЕ, в зависимости от объема фибриноторакса [7].

Доказать наличие фибриноторакса и контролировать изменения в плевральной полости также позволяла плеврография (введение водорастворимого контраста) при полипозиционном рентгеноскопическом исследовании после дренирования или микродренирования плевральной полости. Как правило, экспозиция раствора с террилитином составляла 4-6 ч, после чего дренаж открывали, промывали стерильным физиологическим раствором и присоединяли к герметичному контейнеру. Полученную жидкость отправляли на исследование. После эвакуации всей жидкости выполнялось УЗИ плевральной полости, по результатам которого

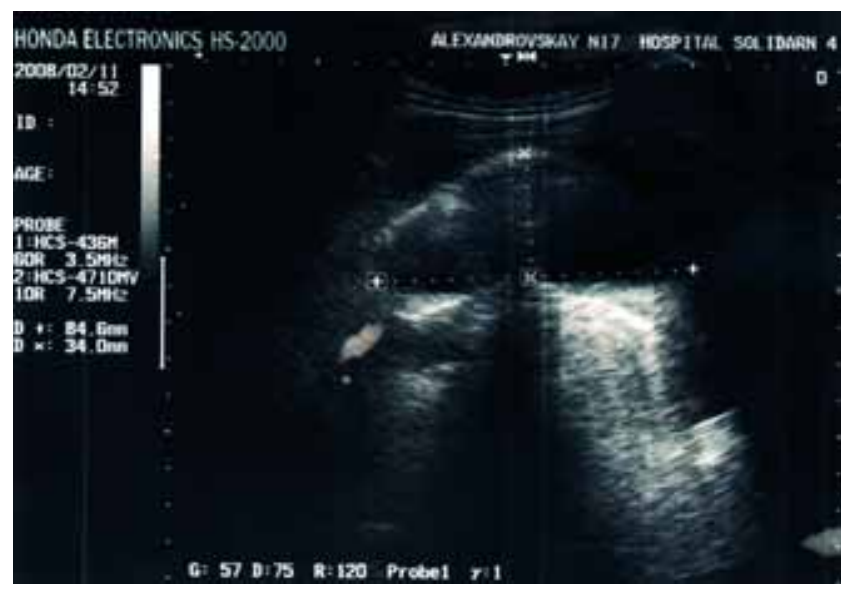

Рис. 2. УЗ-картина фибриноторакса небольшого объема (150 мл). Больной М., 25 лет 
принималось решение о необходимости повторного введения протеолитических ферментов.

При фибринотораксе небольшого объема (100300 мл), микродренирование не проводилось (рис. 2). Под УЗ-контролем, после неудачной попытки аспирировать жидкость во время пункции, в плевральную полость вводился раствор (20-40 мл), содержащий террилитин в дозе 400 ПЕ, из верхней точки полости. Затем, через 4-8 ч (в дневное время, для наблюдения за пациентом), лизированное содержимое плевральной полости эвакуировали широкопросветной иглой под УЗ-контролем при повторной пункции. Полученную жидкость отправляли для исследования и вводили антибиотики широкого спектра действия при минимальном объеме растворителя (5-7 мл).

Некоторым пациентам выполнялась спиральная КТ органов грудной клетки после лечения, чтобы точно определить эффективность санации плевральной полости протеолитическими ферментами.

\section{Результаты и обсуждение}

Предложенные лечебно-диагностические мероприятия проводились 57 пациентам (основная группа), находившимся на лечении в пульмонологическом отделении Александровской больницы в 2007-2008 гг. Среди них были 16 женщин и 41 мужчина. Возраст колебался от 20 до 75 лет, в среднем - 47 лет.

Основной причиной фибриноторакса был неспецифический воспалительный плеврит (пара- и метапневмонический) и туберкулезный плеврит. Так, в основной группе у 31 пациента фибриноторакс являлся следствием пара- или метапневмонического экссудативного плеврита (все больные выписаны с полным выздоровлением), у 17 человек фибриноторакс осложнил течение плеврита туберкулезной этиологии (переведены в противотуберкулезные диспансеры по месту жительства). У 4 пациентов плевральный выпот представлял собой транссудат, но в связи с многократными пункциями и длительным сроком нахождения жидкости в плевральной полости произошло частичное отграничение ее от свободной плевральной полости, и, как следствие, возник фибриноторакс. У 3 пациентов имелся канцероматозный плеврит, и протеолитические ферменты применялись лишь в случаях, когда выявлялось отграниченное скопление жидкости, оставшейся пос- ле удаления ее свободной части. Это делалось для объединения плевральной полости и последующей индукции плевродеза (выполнена индукция плевродеза суспензией талька).

При отрицательных результатах исследования плевральной жидкости (показатели количества лейкоцитов, лейкоцитарной формулы, удельного веса и уровня белка, содержания лактатдегидрогеназы, глюкозы, липидов - в пределах нормы, а также отсутствие атипичных клеток, микобактерий туберкулеза), полученной после применения протеолитических ферментов (террилитина), а также при наличии тенденции к накоплению жидкости для верификации этиологии фибриноторакса и санации плевральной полости выполнялась торакоскопия под местным обезболиванием с последующей биопсией $[3,8,9]$. Для этого с помощью УЗИ намечалась оптимальная точка для микродренирования по методике Сельдингера [3]. После микродренирования и эвакуации основного объема жидкости выполнялся рентгенологический контроль, который позволял оценить возможность свободного расправления легкого или проявления признаков его ригидности [6]. Оставался объем жидкости $\leq 300$ мл, что позволяло беспрепятственно ввести троакар в плевральную полость, не повреждая легкое. Торакоцентез выполнялся под У3-контролем 5- или 7-миллиметровым троакаром. Торакоскопия проводилась под местной анестезией с использованием, как правило, приборов с инструментальным каналом (торакоскоп, бронхоскоп, гистероскоп и т. п.), позволяющих аспирировать остаточную жидкость из плевральной полости, осуществить осмотр плевральной полости и выполнить щипковую биопсию. После этого устанавливали дренаж с подключением к вакуум-аспиратору с разрежением 25-30 см вод. ст.

Торакоскопия с биопсией выполнена у 18 пациентов. Из них у 10 человек был диагностирован специфицеский отграниченный плеврит, у 1 - канцероматозный плеврит, и у 5 больных плеврит носил пара- или метапневмонический характер. Однако у 2 пациентов этиологию синдрома плеврального выпота и фибриноторакса верифицировать не удалось, даже применяя протеолитические ферменты и торакоскопию с биопсией, т. к. полученный материал был неинформативным. Для дальнейшего обследования и лечения эти больные были переведены в специализированные стационары.

Таблица

Исходы лечения фибриноторакса в контрольной и основной группе

\begin{tabular}{l|c|c}
\multicolumn{1}{c|}{ Результаты лечения } & $\begin{array}{c}\text { Основная группа (применение протео- } \\
\text { литических ферментов и торакоскопии) }\end{array}$ & $\begin{array}{c}\text { Контрольная группа (традиционные } \\
\text { методы обследования и лечения) }\end{array}$ \\
\hline Выписаны с верификацией диагноза после лечения, $n$ (\%) & 38 (66) & 16 (21) \\
\hline $\begin{array}{l}\text { Переведены с верификацией диагноза в специализированные } \\
\text { стационары, } n \text { (\%) }\end{array}$ & $17(30)$ & $8(10)$ \\
\hline $\begin{array}{l}\text { Не удалось верифицировать и санировать плевральную полость } \\
\text { (переведены в специализированные стационары), } n(\%)\end{array}$ & $2(4)$ & $39(53)$ \\
\hline Эмпиема плевры, $n$ (\%) & - & $5(7)$ \\
\hline $\begin{array}{l}\text { Формирование мощного фиброторакса, } n \text { (\%) } \\
\text { Всего, } n(\%)\end{array}$ & - & $7(9)$ \\
\hline
\end{tabular}


Продолжительность терапии в основной группе составила от 3 до 14 сут., в среднем - 8 сут. После торакоскопии дренаж удалялся через 1-3 сут., осложнения отсутствовали.

Как видно из таблицы, в результате предложенных лечебно-диагностических мероприятий у больных с плевритом отграниченного характера (ФТ) достоверность в установлении этиологии фибриноторакса составила $96 \%$, т. е. была в 3 раза выше, чем при традиционной методике (32\%). Осложнений в виде эмпиемы плевры, формирования мощного фибриноторакса не выявлено ни в одном случае. Удалось сократить продолжительность терапии на 6-7 сут.

Таким образом, значительно повысилась эффективность диагностики и лечения осумкованного плеврита, независимо от причины его возникновения, т. е. удалось осуществить полноценную санацию плевральной полости с помощью малоинвазивных манипуляций.

\section{Заключение}

1. Предложенная программа лечебно-диагностических мероприятий с использованием УЗ-диагностики, протеолитических ферментов, торакоскопии под местным обезболиванием оказалась высокоэффективной, по сравнению с традиционными методами лечения и обследования.

2. Применение данной системы позволяет улучшить результаты и сократить сроки лечения у пациентов с фибринотораксом. Ее можно использовать практически во всех многопрофильных стационарах.

\section{Литература}

1. Соколов В.А. Плевриты. Екатеринбург: Изд-во "Баско", 1998.

2. Шулутко А.М., Овчинников А.А., Ясногородский О.О., Мотус И.Я. Эндоскопическая торакальная хирургия. М.: Медицина; 2006.

3. Щемелев А.А. Видеоторакоскопия в комплексной диагностике и лечении экссудативных плевритов неясной этиологии: Дис. ... канд. мед. наук. СПб.; 2007.

4. Варин А.А., Стрекалис А.К., Ханин А.Л. Заболевания плевры. Томск: Красное знамя; 2003.

5. Агафонов А.Н. Прогнозирование результатов хирургического лечения неспецифических воспалительных заболеваний легких и плевры на основе стандартизации и кодирования фибротораксов: Автореф. дис. ... канд. мед. наук. Архангельск; 2006.

6. Ищенко Б.И., Бисенков Л.Н., Тюрин И.Е. Лучевая диагностика для торакальных хирургов: Руководство для врачей. СПб.: ДЕАН; 2001.

7. Чепчерук Г.С. Патогенетические основы профилактики и лечения неспецифической эмпиемы плевры: Дис. ... д-ра мед. наук. Ленинград; 1986.

8. Алиев М.А., Иоффе Л.Ц., Дашиев В.А. и др. Диагностическая и оперативная торакоскопия. Алма-Ата: Наука; 1988.

9. Лукомский Г.И., Овчинников А.А., Этис Э.Е. Торакоскопия в диагностике плеврита неясной этиологии. Грудная хир. 1977; 1: 56-59.

\section{Информация об авторах}

Лишенко Виктор Владимирович - к. м. н., доцент кафедры хирургии им. Н.Д.Монастырского Санкт-Петербургской медицинской академии последипломного образования; тел.: (812) 583-16-24

Зайцев Давид Александрович - ст. лаборант кафедры хирургии им. Н.Д.Монастырского; тел.: (812) 583-16-24; e-mail: monastyrskiy @mail.ru 